\title{
Możliwości zastosowania nanorurek węglowych (CNTs) w technologii zaczynów cementowych
}

\section{The possibility of using carbon nanotubes in cement slurries technology}

\author{
Miłosz Kędzierski, Marcin Rzepka, Marcin Kremieniewski \\ Instytut Nafty i Gazu - Państwowy Instytut Badawczy
}

\begin{abstract}
STRESZCZENIE: Artykuł przedstawia wyniki badań wpływu nanorurek węglowych (CNTs) na parametry reologiczne zaczynu cementowego oraz mechaniczne kamienia cementowego. Do zaczynów dodawano $0,1 \%$ i $0,2 \%$ nanorurek węglowych. Receptury cementowe opracowane były w Instytucie Nafty i Gazu - Państwowym Instytucie Badawczym, w Laboratorium Zaczynów Uszczelniających. Zaczyny posiadały gęstość od około $1830 \mathrm{~kg} / \mathrm{m}^{3}$ do około $1870 \mathrm{~kg} / \mathrm{m}^{3}$, a ich sporządzanie odbywało się na bazie cementu portlandzkiego CEM I 42,5. Badania wytrzymałości na ściskanie i przyczepności do rur prowadzono po 2, 7, 14 i 28 dniach, pomiar porowatości wykonano po 28 dniach hydratacji. Opracowano receptury o bardzo dobrych parametrach technologicznych, które po utwardzaniu (po okresie 28 dni hydratacji) posiadały bardzo wysokie wartości wytrzymałości na ściskanie, dochodzące nawet do $51 \mathrm{MPa}$ (dla zaczynu z dodatkiem $0,1 \%$ nanorurek węglowych) oraz $36,8 \mathrm{MPa}$ (dla zaczynu z dodatkiem $0,2 \%$ nanorurek węglowych). Tak wysokie wartości wytrzymałości są niezwykle trudne do uzyskania w przypadku zastosowania zaczynów konwencjonalnych. Optymalną ilością CNTs jest dodatek $0,1 \%$. Po dodaniu $0,2 \%$ CNTs otrzymano niższe wartości wytrzymałości na ściskanie, co może być spowodowane niedostatecznym rozproszeniem nanocząsteczek w zaczynie. Uzyskano wysokie wartości przyczepności kamienia cementowego do rur oraz zaobserwowano zmniejszenie filtracji zaczynu w porównaniu z zaczynem bazowym. Otrzymane kamienie cementowe posiadały niską porowatość, a rozkład ich porów charakteryzował się niewielką ilością porów o średnicach powyżej $100 \mathrm{~nm}$ (średnio w granicach 1,3-2,8\%), co świadczy o ich zwartej strukturze. W wyniku przeprowadzonych badań można zauważyć pozytywny wpływ dodatku nanorurek węglowych na wytrzymałość oraz mikrostrukturę kamieni cementowych z ich dodatkiem. Uzyskane wyniki umożliwiają określenie wpływu dodatku nanorurek węglowych na zaczyn i kamień cementowy i są wstępem do dalszych badań w tym kierunku.
\end{abstract}

Słowa kluczowe: nanorurki węglowe, kamień cementowy, wytrzymałość na ściskanie, zaczyn cementowy.

\begin{abstract}
The article presents the results of testing the influence of carbon nanotubes on the mechanical and rheological properties of cement slurry and stone. 0.1 and $0.2 \%$ carbon nanotubes were added to the cement slurry. Laboratory tests of cement slurries were carried out at Oil and Gas Institute - National Research Institute. The densities of tested slurries ranged from 1830 to $1870 \mathrm{~kg} / \mathrm{m}^{3}$, and were prepared on the basis of CEM I 42.5 Portland cement. Compressive strength tests and adhesion measurements were carried out after 2, 7, 14 and 28 days, while porosity after 28 days. Cement slurry recipes with very good technological parameters were developed, with very high compressive strength values after curing (after 28 days of hydration), reaching up to $51 \mathrm{MPa}$ (for slurry with the addition of $0.1 \% \mathrm{CNTs}$ ) and $36.8 \mathrm{MPa}$ (for slurry with the addition of $0.2 \% \mathrm{CNTs}$ ). Such high compressive strength values are extremely difficult to obtain with conventional cement slurries. When $0.2 \% \mathrm{CNTs}$ was added, lower compressive strength values were obtained, which may be due to difficulty in uniform distribution of large quantities of nanoparticles in the slurry. Cements were characterized by high values of adhesion to pipes and smaller fluid loss - compared to basic cement slurry. The obtained set cement slurries had low porosity and their pore distribution was characterized by a small number of pores with diameters greater than $100 \mathrm{~nm}$, within the range of 1.3-2.8\%, which prove their compact structure. As a result of the research, it can be stated that the addition of carbon nanotubes has a positive effect on the mechanical strength and microstructure of cement stones. The obtained results allow to determine the influence of carbon nanotubes on the cement slurry and stone and are initial research in this direction.
\end{abstract}

Key words: carbon nanotubes (CNTs), cement stone, compressive strength, cement slurry.

Autor do korespondencji: M. Kędzierski, e-mail: milosz.kedzierski@inig.pl

Artykuł nadesłano do Redakcji: 14.11.2019 r. Zatwierdzono do druku: 24.01.2020 r. 


\section{Wprowadzenie}

Nanotechnologia jest współcześnie jedną z najszybciej rozwijających się dziedzin zarówno nauki, jak i techniki, obejmującą szereg dyscyplin, w tym inżynierię lądową i materiały budowlane. Obecnie najbardziej aktywnymi obszarami badawczymi związanymi z technologią cementu i betonu są: dokładne poznanie procesu uwodnienia cząstek cementu i zastosowanie składników o rozmiarze nano, takich jak cząstki tlenku glinu i nanorurki węglowe. Oczekuje się, że nanorurki węglowe (CNTs) posiadają wiele właściwości mogących znaleźć zastosowanie jako materiał wzmacniający dla cementów. Efekty końcowe nowo powstałych kompozytów z dodatkiem CNTs będą znacznie lepsze niż w przypadku bardziej tradycyjnych włókien. Po pierwsze, CNTs mają znacznie większą wytrzymałość niż inne włókna, co powinno poprawić ogólne parametry mechaniczne. Po drugie, nanorurki węglowe posiadają znacznie wyższe współczynniki proporcji, wymagające znacznie wyższych energii propagacji pęknięć wokół rurki niż w przypadku włókien o niższym współczynniku kształtu. Po trzecie, mniejsze średnice CNTs oznaczają zarówno to, że mogą być one lepiej rozmieszczone w matrycy cementowej ze zmniejszonymi odstępami włókien, jak i to, że ich oddziaływanie z matrycą może być inne od interakcji większych włókien. Zastosowanie cementu wzmocnionego CNTs może zmniejszyć prawdopodobieństwo zgniecenia rur okładzinowych w odwiertach naftowych i gazowych. Migracja gazu jest jednym z problemów cementowania w odwiertach gazowych. Wykorzystanie CNTs w zaczynie cementowym może zmniejszyć możliwość występowania tego niekorzystnego zjawiska.

Cementowanie jest jedną z najważniejszych operacji prowadzonych podczas wykonywania otworu wiertniczego. Prawidłowe przeprowadzenie tego zabiegu decyduje o późniejszej eksploatacji odwiertu. Celem cementowania jest uzyskanie jak najlepszego związania rur okładzinowych z formacją skalną i osiągnięcie izolacji strefowej w otworze wiertniczym. Oprócz tego płaszcz cementowy chroni również rury okładzinowe przed korozją oraz obciążeniami podczas głębokich wierceń. W trakcie operacji cementowania zaczyn, składający się głównie z wody, cementu i chemikaliów kontrolujących parametry zaczynu cementowego, jest wtłaczany do otworu i umieszczany w cementowanym interwale $\mathrm{w}$ przestrzeni pierścieniowej między kolumną rur okładzinowych a formacją geologiczną otaczającą odwiert i pozostawiany jest do związania. Głównym wyzwaniem cementowania jest osiągnięcie pełnej izolacji strefowej. Oznacza to, że należy uzyskać uszczelnienie między cementem a rurami okładzinowymi, jak również między cementem a formacją w cementowanym interwale. $\mathrm{W}$ razie braku otrzymania pełnego uszczelnienia odwiert nigdy nie osiągnie pełnego potencjału eksploatacji ropy naftowej lub gazu ziemnego.

Jak w każdej dziedzinie nauki, także w wiertnictwie dąży się do tworzenia nowych, ulepszonych i przyjaznych środowisku produktów. Dlatego też poszukiwanie alternatywnych materiałów do cementowania otworów wiertniczych rozwija się na całym świecie bardzo szybko. Wymagane jest, aby z tych niekonwencjonalnych materiałów powstał cement, który jest mocniejszy, trwalszy czy też bardziej ekologiczny (Patil i Deshpande, 2012).

Nanonauka i nanotechnologia znalazły zastosowanie w przemyśle naftowym i są wykorzystywane w wielu obszarach, tj. technologii płuczkowej i cementowania. W ciągu ostatnich kilku lat wielu naukowców przeprowadziło badania związane z poprawą i zrozumieniem zachowania zaczynów cementowych z dodatkiem nanomateriałów. Przebadano kilka rodzajów nanomateriałów, takich jak nanokrzemionka, nanoił, nanotlenki żelaza, glinu, cynku i tytanu (Rahman et al., 2016; Dębińska, 2014, 2015, 2016; Rahman i Murtaza, 2015; Dębińska et al., 2016). Włączenie materiałów nanometrycznych do struktury hydratu krzemianu wapnia (C-S-H) skutkuje mocniejszą i bardziej plastyczną matrycą cementową, która może zapobiec propagacji pęknięć w stwardniałym zaczynie (Roij et al., 2012).

Nanorurki węglowe (CNTs), jako nanomateriały, obecnie cieszą się bardzo dużym zainteresowaniem ze względu na swoje unikatowe i cenne właściwości, takie jak wytrzymałość na rozciąganie, moduł sprężystości, elektryczne i termiczne przewodnictwo (Dresselhaus et al., 1996). Wiele ośrodków naukowych podejmuje tematykę badawczą związaną z nanomateriałami węglowymi ze względu na ich obecne i liczne perspektywiczne zastosowania (Kuilla et al., 2010; Huang et al., 2012; Nasibulin et al., 2013).

W niniejszej pracy podjęto nowatorskie badania nad zastosowaniem nanorurek węglowych w technologii zaczynów cementowych używanych do uszczelniania otworów wiertniczych.

\section{Nanotechnologia i nanorurki węglowe}

Słowo „nano” pochodzi z języka greckiego i oznacza „karzeł" (mały); podejście naukowe na poziomie nano (poziom atomowy) za pomocą specjalnych instrumentów naukowych jest znane jako technologia, która stała się dobrze znaną dziedziną w ciągu ostatnich trzech dekad (Saeed i Khan, 2013). Słowo „nanotechnologia” wymyślił w 1974 roku w Japonii Norio Taniguchi. Stwierdził on, że nanotechnologia składa się głównie z etapów przetwarzania, oddzielania, konsolidacji i deformacji materiałów przez jeden atom lub jedną cząsteczkę 
(Taniguchi, 1974). Nanotechnologia to rozległa dziedzina, która bada wiele faktów na temat struktur i właściwości materiałów. Unikalne właściwości nanocząsteczek i nanokompozytów sprawiły, że są one przydatne w różnych dziedzinach nauki, między innymi w elektronice, optyce, medycynie i budownictwie. Jednym z najciekawszych materiałów są nanorurki węglowe, które ze względu na swe wyjątkowe właściwości fizyczne, chemiczne, mechaniczne, elektryczne, a także magnetyczne znalazły szerokie zastosowanie w wielu gałęziach nauki. Wykorzystywane są od manipulacji strukturą żywej materii po obwody komputerowe oraz kompozyty wielkości nanometrów. Są one obiecującym materiałem do zastosowania w wielu innowacyjnych rozwiązaniach (Dai, 2002; Popov, 2004; Szadkowski i Pingot, 2016).

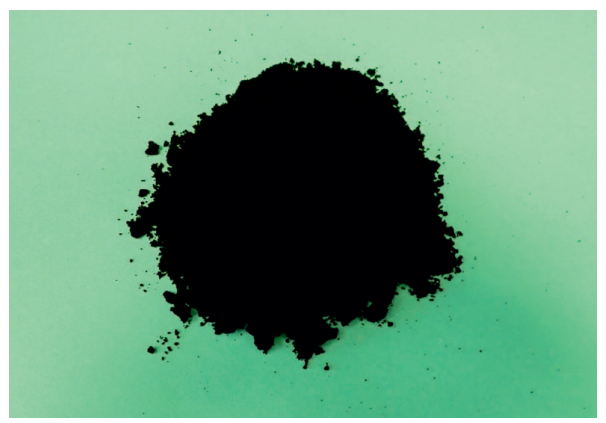

Rys. 1. Wielościenne nanorurki węglowe o średnicy zewnętrznej 10-20 nm i długości 10-30 $\mu \mathrm{m}$ (w postaci proszku) używane w badaniach laboratoryjnych

Fig. 1. Multi-Walled Carbon Nanotubes with an outer diameter of 10-20 nm and a length of 10-30 um (in the form of powder) used in laboratory tests

Nanorurki węglowe zostały odkryte przez Sumio Iijimę w 1991 roku za pomocą mikroskopu elektronowego o wysokiej rozdzielczości (HREM), co spowodowało rozpoczęcie związanych z nimi intensywnych badań eksperymentalnych i teoretycznych (Pandey i Dahiya, 2016).

Nanorurki węglowe stanowią jedną z odmian alotropowych węgla. Zbudowane są ze zwiniętych cylindrycznie warstw grafenowych. Nanorurki mają postać czarnego proszku (rys. 1). Są praktycznie nierozpuszczalne w wodzie i w rozpuszczalnikach organicznych. Nanorurki węglowe różnią się między sobą długością, średnicą, a także kątem skrętności. Z powodu oddziaływania sił van der Waalsa między ścianami nanorurek ulegają one agregacji. Konieczne jest więc rozdzielenie wiązek nanorurek na pojedyncze nanorurki. Dokonuje się tego, poddając zawiesinę nanorurek działaniu ultradźwięków. Nanorurki węglowe mają bardzo dużą wytrzymałość teoretyczną, która jest około 100 razy większa niż w przypadku stali, przy 6-krotnie niższej wadze. Moduł Younga i wytrzymałość na rozciąganie wynoszą odpowiednio 1 TPa i $200 \mathrm{GPa}$.

\section{Modele nanorurek węglowych}

Ze względu na ich budowę nanorurki możemy podzielić na:

- jednościenne (ang. single-walled carbon nanotubes - SWCNTs);

- dwuścienne (ang. double-walled carbon nanotubes - DWCNTs);

- wielościenne (ang. multi-walled carbon nanotubes - MWCNTs).

Wielościenne nanorurki węglowe zbudowane są ze współosiowych warstw grafenowych. Średnica zewnętrzna MWCNTs może wynosić do kilkudziesięciu nanometrów. Natomiast średnica rdzenia nie przekracza kilkunastu nanometrów (Bachmatiuk, 2008). Wymiary i właściwości nanorurek węglowych zależą od charakteru metody ich wytwarzania. Można wyróżnić następujące metody otrzymywania wielościennych nanorurek węglowych: wyładowanie w łuku elektrycznym (Iijima i Ichihashi, 1993; Ando, 1994), laserowe parowanie (Puretzky et al., 2000; Maser et al., 2002), chemiczne osadzanie par (Oncel i Yurum, 2006). Metoda chemicznego osadzania z fazy gazowej (CVD) wzbudza duże zainteresowanie z powodu możliwości otrzymywania nanorurek węglowych o wysokiej czystości na dużą skalę (Li X. et al., 2005; Musso et al., 2007).

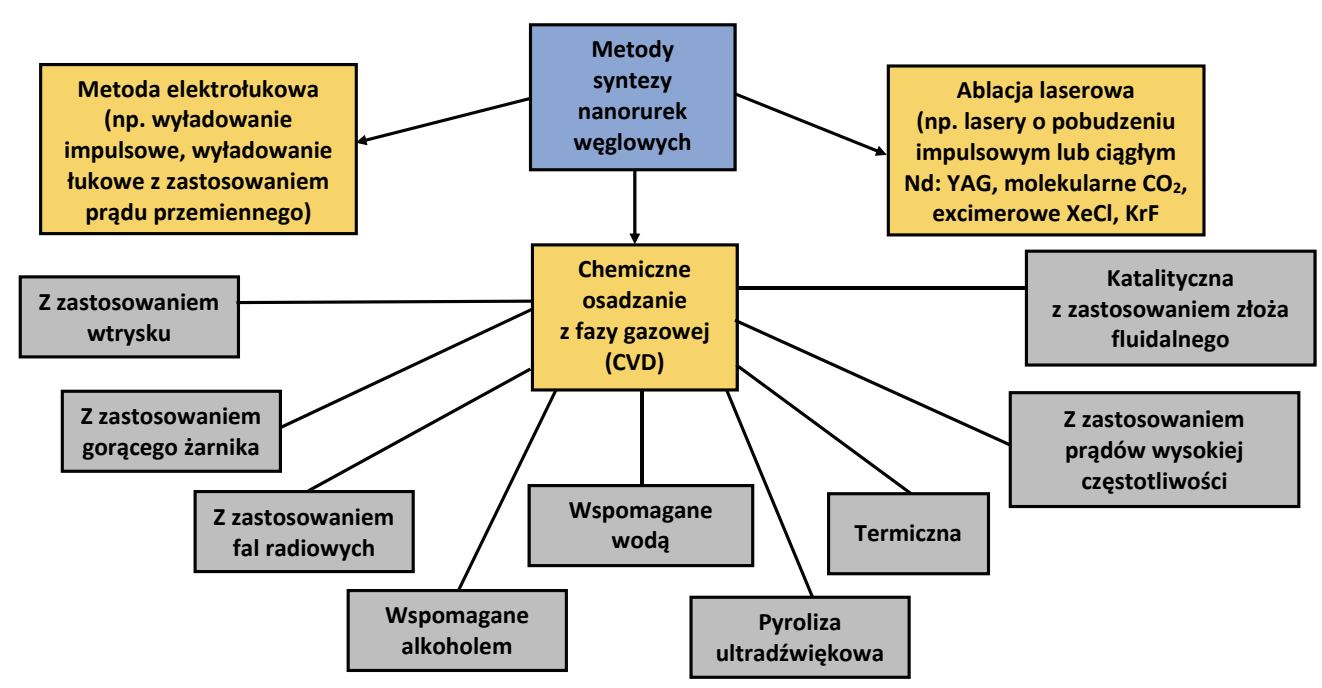

Rys. 2. Metody wytwarzania nanorurek węglowych (Dobrzańska-Danikiewicz et al., 2015)

Fig. 2. Methods for producing carbon nanotubes (Dobrzańska-Danikiewicz et al., 2015) 


\section{Wpływ nanorurek węglowych na właściwości zaczynów cementowych}

W ostatnim dziesięcioleciu nanotechnologia została z powodzeniem zastosowana w materiałach budowlanych. Jedną z najbardziej pożądanych właściwości nanomateriałów w sektorze budowlanym jest ich zdolność do nadawania mechanicznego wzmocnienia w strukturze materiałów na bazie cementu. Nanorurki węglowe (CNTs) mają doskonałe właściwości mechaniczne i dlatego w połączeniu ze zwykłym cementem portlandzkim mogą tworzyć nanokompozyty twardsze niż tradycyjne materiały wzmacniające (np. włókna szklane lub włókna węglowe) (de Morais i Haddad, 2014). Ze względu na swój rozmiar (od $1 \mathrm{~nm}$ do kilkudziesięciu nanometrów) i współczynniki kształtu, CNTs mogą być rozmieszczone w znacznie drobniejszej skali niż zwykłe włókna, co daje w efekcie bardziej wydajne mostkowanie pęknięć na wstępnym etapie pękania. Dodanie CNTs prowadzi do wzrostu ilości kryształów hydratów powstających w paście cementowej i zmianę ich struktury morfologicznej (Al-Saud et al., 2011). Pozytywny wpływ nanorurek węglowych na właściwości sprężyste kamienia cementowego jest wyraźnie widoczny w skali makroskopowej przy użyciu urządzenia ultradźwiękowego (Eberhardsteiner et al., 2011). Dotychczasowe badania wykazały, iż dodatek nanorurek węglowych może zwiększyć wytrzymałość matrycy cementowej. Stwierdzono, że mała ilość skutecznie rozproszonych CNTs może znacznie zwiększyć wytrzymałość na zginanie. Dodatek krótkich, wielościennych CNTs w ilości $0,08 \%$ spowodował wzrost wytrzymałości na zginanie do $35 \%$ oraz zwiększenie się modułu Younga (Kosta-Gdoutos et al., 2010; Wang et al., 2013). Jeszcze lepsze wyniki uzyskano w przypadku wytrzymałości na ściskanie. Dodatek CNTs w ilości 1,0\% w stosunku do masy cementu doprowadził do wzrostu wytrzymałości na ściskanie do wartości 51,8 MPa po 28 dniach hydratacji (Li G.Y. et al., 2005; Chaipanich et al., 2010; Al-Saud et al., 2011). W innych badaniach stwierdzono, iż dodatek nanorurek do kompozytów cementowych spowodował spadek wytrzymałości na ściskanie (Collins et al., 2012). Modyfikacja zaczynu cementowego za pomocą dodatku CNTs w ilości 0,5\% (bwoc) spowodowała spadek wytrzymałości na ściskanie o około $80 \%$ (Musso et al., 2009). Zróżnicowany wpływ dodatków CNTs na właściwości mechaniczne materiałów cementowych można prawdopodobnie wyjaśnić różnymi wyborami rodzaju i ilości CNTs oraz metodami rozpraszania nanorurek. Wyniki pomiaru porowatości oraz rozkładu wielkości porów wskazują, że cement zawierający CNTs miał mniejszą porowatość i bardziej jednolity rozkład wielkości porów (Kosta-Gdoutos et al., 2010; Wang et al., 2013). Nanorurki węglowe działają jako wypełniacz matrycy cementowej
(Nochaiya i Chaipanich, 2011). Nanomodyfikowane kompozyty mają wyższy stopień sztywności C-S-H (Kosta-Gdoutos et al., 2010).

Głównym problemem stosowania nanorurek jest ich skłonność do aglomeracji oraz niska przyczepność do pasty cementowej (Kosta-Gdoutos et al., 2010). Nierównomiernie rozmieszczone CNTs nie mogą tworzyć cienkiej, ciągłej sieci w matrycy, aby wspierać przenoszenie obciążenia lub łagodzić rozwój pęknięć. Ponadto aglomeraty CNTs mogą działać jako lokalne defekty ze względu na swą niską wytrzymałość w kierunku prostopadłym do osi rurek (Sàez de Ibarra et al., 2006). Ze względu na hydrofobowy charakter trudno jest rozproszyć CNTs w matrycy cementowej. W celu uzyskania jednorodnej dyspersji CNTs w roztworze wodnym, a następnie mieszance betonowej zastosowano wiele różnych domieszek (Collins et al., 2012; Sobolkina et al., 2012). Aby osiągnąć korzystny wpływ CNTs na mechaniczne właściwości kompozytów cementowych, konieczne jest odpowiednie rozproszenie CNTs (Musso et al., 2009). Najlepsze wyniki pod względem wytrzymałości na ściskanie dla zaczynów cementowych modyfikowanych CNTs uzyskano poprzez zdyspergowanie CNTs przy użyciu sonifikacji (Kosta-Gdoutos et al., 2010). Procesory ultradźwiękowe przetwarzają napięcie sieciowe na wibracje mechaniczne. Te mechaniczne wibracje są przenoszone do cieczy przez sondę, tworząc falę ciśnienia. To działanie powoduje powstawanie i gwałtowne zapadanie się mikroskopijnych bąbelków. Zjawisko to, określane jako kawitacja, tworzy miliony fal uderzeniowych, zwiększając temperaturę cieczy (Hielscher, 2006). Rozpad kawitacyjny trwa tylko kilka mikrosekund. Chociaż ilość energii uwalnianej przez każdą pojedynczą bańkę jest niewielka, skumulowany efekt sprawia, że uwalniane są ekstremalnie wysokie poziomy energii, powodując rozproszenie obiektów i powierzchni wewnątrz pola kawitacyjnego. Jednakże wiedza na temat kształtu i długości CNTs w utwardzonym zaczynie cementowym, a także ich pozycji względem pustek i produktów hydratacji jest niewielka. Należy również wyjaśnić, w jakim stopniu wytrzymałość i sztywność CNTs mają bezpośredni wpływ na poprawę właściwości mechanicznych kamienia cementowego i jakie są inne efekty, np. wywołanie powstawania faz C-S-H o dużej gęstości w obecności CNTs.

Wpływ nanorurek węglowych na kompozyty cementowe jest ograniczony ze względu na ich wysoką cenę. Nawet przy niewielkich dodawanych ilościach obecne ceny nanorurek węglowych są zbyt wysokie, żeby produkcja ważnych struktur kompozytowych była opłacalna. Materiał kompozytowy z dodatkiem CNTs może być zastosowany w aplikacjach, w których wymaganie uzyskania ultrawysokich twardości i wytrzymałości rekompensuje cenę nanorurek i potencjalne trudności. Nanotechnologia oferuje możliwości precyzyjnego 
konstruowania cementu do specyficznych zastosowań, redukcję późniejszych kosztów i wzrost wydajności.

\section{Badania laboratoryjne}

Badania laboratoryjne mające na celu analizę możliwości zastosowania nanorurek węglowych w technologii zaczynów cementowych były wykonywane w Zakładzie Technologii Wiercenia INiG - PIB Oddział Krosno w Laboratorium Zaczynów Uszczelniających zgodnie z normami API Spec 10: Specification for Materials and Testing for Well Cements, Przemyst naftowy i gazowniczy - Cementy i materiaty do cementowania otworów - Część 1: Specyfikacja (PN-EN ISO 10426-1:2009) oraz Przemyst naftowy i gazowniczy - Cementy i materiaty do cementowania otworów wiertniczych-Część 2. Badania cementów wiertniczych (PN-EN ISO 10426-2:2003).

Dla każdego zaczynu cementowego wykonano pomiar parametrów reologicznych i filtracji, a dla uzyskanych kamieni cementowych - badania wytrzymałości na ściskanie po 2 , 7, 14 i 28 dniach, a także badanie porowatości oraz przyczepności do rur stalowych.

W badanych zaczynach cementowych jako spoiwo wiążące zastosowano cement portlandzki CEM I 42,5 R. Zaczyny cementowe sporządzano na wodzie wodociągowej. Zaczyny cementowe opierały się na standardowym zaczynie cementowym z dodatkiem nanorurek węglowych. W badaniach zastosowano wielościenne nanorurki węglowe (MWCNTs) o średnicy zewnętrznej 10-20 nm i długości 10-30 $\mu \mathrm{m}$ oraz czystości powyżej 95\%. Zaczyny cementowe sporządzano na wodzie wodociągowej. Zawierały one: upłynniacz, dodatek odpieniający, dodatek antyfiltracyjny, dodatek przyspieszający wiązanie $\mathrm{CaCl}_{2}$, dodatek spęczniający, $\mathrm{KCl}$ oraz nanorurki węglowe. Stosunek w/c wynosił 0,45-0,49. Nanorurki węglowe dodawano do wody i dyspergowano je przy użyciu sonifikatora Sonics VC 505 (amplituda 70\%, czas 3 minuty). Badania przeprowadzono w temperaturze $25^{\circ} \mathrm{C}$ (właściwości reologiczne i mechaniczne) oraz $30^{\circ} \mathrm{C}$ (czas gęstnienia i filtracja). Wykonano próbkę porównawczą niezawierającą dodatku nanorurek węglowych.

\section{Wyniki badań}

Poniżej przedstawiono wyniki badań bazowego zaczynu cementowego oraz optymalnych zaczynów cementowych $\mathrm{z}$ dodatkiem nanorurek węglowych.

Zaczyn bazowy charakteryzował się odpowiednimi parametrami reologicznymi oraz zerowym odstojem wody. Uzyskał on konsystencję $30 \mathrm{Bc}$ po czasie 1 godz. $21 \mathrm{~min}$, a $100 \mathrm{Bc}$ po 4 godz. Filtracja zaczynu miała wartość $186 \mathrm{~cm}^{3}$. Wytrzymałość kamienia cementowego na ściskanie po 28 dniach była równa 33,4 MPa. Wartości wytrzymałości kamienia cementowego otrzymane po 2, 7, 14 i 28 dniach hydratacji przedstawia rysunek 3. Porowatość zaczynu bazowego wynosiła 37,4\%. Pory największe (o średnicy powyżej $10000 \mathrm{~nm}$ ) stanowiły około 1,5\% całkowitej ilości porów, pory o wielkości od $10000 \mathrm{~nm}$ do 100 nm zajmowały około $34,8 \%$ całości. Najmniejsze pory, o średnicy poniżej 100 nm, stanowiły około 63,8\% całości porów (rys. 4).

Zaczyn nr 1, zawierający 0,1\% nanorurek węglowych (MWCNTs), charakteryzował się dobrymi parametrami reologicznymi. Zaczyn ten uzyskał konsystencję $30 \mathrm{Bc}$ po czasie 1 godz. $25 \mathrm{~min}$, a 100 Bc po 3 godz. 47 min. Filtracja wynosiła $66 \mathrm{~cm}^{3} / 30 \mathrm{~min}$. Na rysunku 5 zaprezentowano wykres wytrzymałości na ściskanie, zginanie i przyczepność do rur kamienia cementowego. Można stwierdzić, że wytrzymałość na ściskanie wzrasta wraz z upływem czasu. Po 2 dniach wytrzymałość kamienia cementowego wynosiła około $27 \mathrm{MPa}$, a po 28 dniach aż $51 \mathrm{MPa}$. Próbka kamienia cementowego posiadała porowatość wynoszącą 30,9\%. Pory największe (o średnicy powyżej $10000 \mathrm{~nm}$ ) stanowiły około 2,8\% całkowitej ilości porów, pory o wielkości od $10000 \mathrm{~nm}$ do $100 \mathrm{~nm}$ zajmowały około 1,4\% całości. Najmniejsze pory, o średnicy poniżej $100 \mathrm{~nm}$, stanowiły około 95,8\% całości porów (rys. 6).

Zaczyn nr 2, z dodatkiem 0,1\% nanorurek węglowych, podobnie jak zaczyn nr 1 charakteryzował się dobrymi parametrami technologicznymi. Uzyskał on konsystencję $30 \mathrm{Bc}$ po czasie 1 godz. 35 min, a 100 Bc po 4 godz. 25 min. Filtracja wynosiła $60 \mathrm{~cm}^{3} / 30 \mathrm{~min}$. Wytrzymałość kamienia cementowego na ściskanie po 2 dniach była bardzo wysoka i wynosiła 35,0 $\mathrm{MPa}$, a po 28 dniach była równa 41,0 $\mathrm{MPa}$ (rys. 7). Porowatość wynosiła 32,2\%. Pory największe (o średnicy powyżej $10000 \mathrm{~nm}$ ) stanowiły około 1,3\% całkowitej ilości porów, pory o wielkości od $10000 \mathrm{~nm}$ do $100 \mathrm{~nm}$ zajmowały około $15,1 \%$ całości. Najmniejsze pory, o średnicy poniżej 100 nm, stanowiły około 83,6\% całości porów (rys. 8).

Skład i parametry zaczynu nr 3, z dodatkiem 0,2\% CNTs, przedstawiono w tabeli 4. Zaczyn uzyskał $30 \mathrm{Bc}$ po czasie 1 godz. 7 min, a $100 \mathrm{Bc}$ po 3 godz. 14 min. Filtracja wyniosła $70 \mathrm{~cm}^{3} / 30 \mathrm{~min}$. Po upływie 2 dni próbka kamienia badana ma maszynie wytrzymałościowej osiągnęła wytrzymałość na ściskanie 21,9 MPa, a po 28 dniach jej wytrzymałość na ściskanie wzrosła do prawie $37 \mathrm{MPa}$ (rys. 9). Porowatość wynosiła 33,1\%. Rozkład porów w badanej próbce wskazuje na występowanie makroporów w ilości około 1,3\%, co świadczy o wyjątkowo zwartej mikrostrukturze matrycy cementowej (rys. 10). 
Tabela 1. Bazowy zaczyn cementowy

Table 1. Base cement slurry

\begin{tabular}{|c|c|c|c|c|}
\hline \multicolumn{2}{|l|}{ Skład zaczynu } & \multicolumn{3}{|c|}{ Parametry zaczynu } \\
\hline Woda & $\mathrm{w} / \mathrm{c}=0,47$ & \multicolumn{2}{|c|}{ Gęstość $\left[\mathrm{g} / \mathrm{cm}^{3}\right]$} & 1,86 \\
\hline Dodatek upłynniający & $0,075 \%$ & \multicolumn{2}{|c|}{ Rozlewność [mm] } & 220 \\
\hline Dodatek antyfiltracyjny & $0,3 \%$ & \multicolumn{2}{|l|}{ Odstój wody [\%] } & 0,0 \\
\hline Dodatek odpieniający & $0,2 \%$ & \multicolumn{2}{|c|}{ Lepkość plastyczna $[\mathrm{mPa} \cdot \mathrm{s}]$} & 147,0 \\
\hline $\mathrm{KCl}$ & $3,0 \%$ & \multicolumn{2}{|c|}{ Granica płynięcia YP $[\mathrm{Pa}]$} & 10,1 \\
\hline Dodatek przyspieszający wiązanie & $1,0 \%$ & \multirow{2}{*}{ Czas gęstnienia } & $30 \mathrm{Bc}$ [h:min] & $2: 21$ \\
\hline CEM I 42,5 R & $100,0 \%$ & & $100 \mathrm{Bc}[\mathrm{h}: \mathrm{min}]$ & 4:00 \\
\hline Dodatek spęczniający & $0,3 \%$ & \multicolumn{2}{|l|}{ Porowatość [\%] } & 37,4 \\
\hline & & \multicolumn{2}{|c|}{ Filtracja $[\mathrm{ml} / 30 \mathrm{~min}]$} & 186 \\
\hline
\end{tabular}

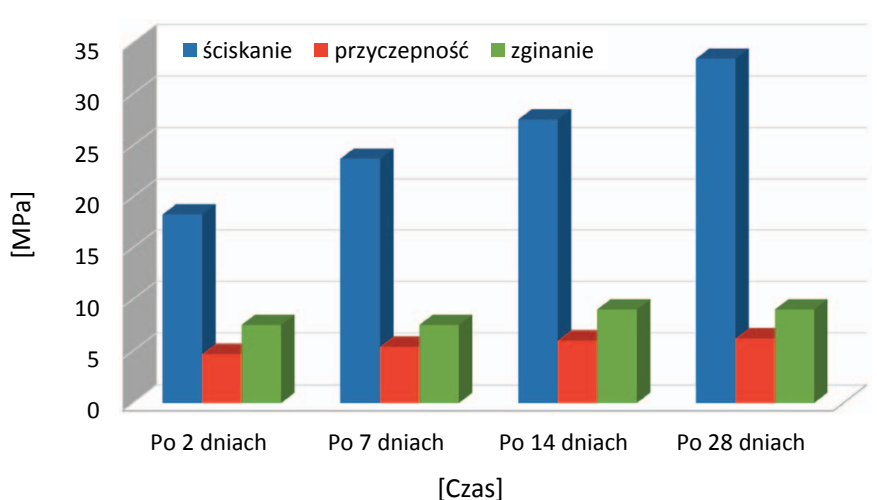

Rys. 3. Wytrzymałość mechaniczna bazowego kamienia cementowego

Fig. 3. Mechanical strength of the base cement stone

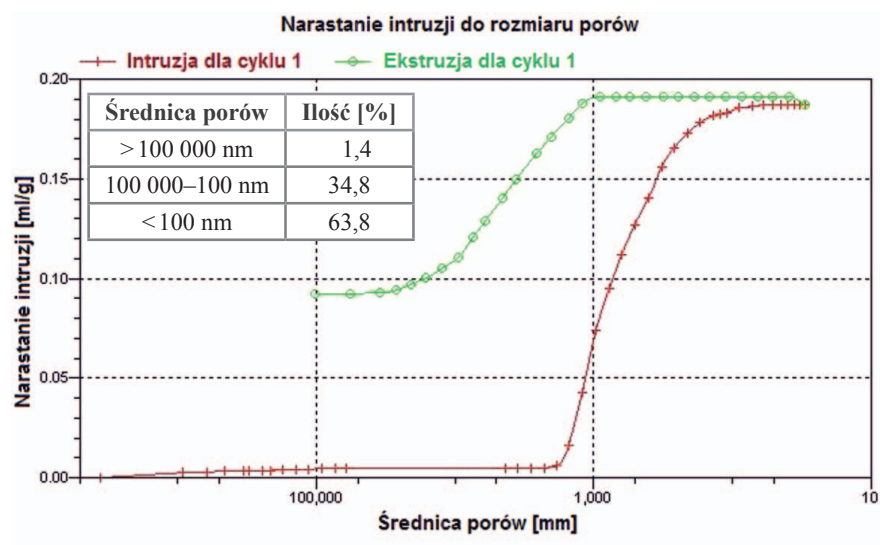

Rys. 4. Rozkład wielkości porów zaczynu bazowego

Fig. 4. Pore size distribution of the base cement slurry

Tabela 2. Zaczyn cementowy nr 1

Table. 2. Cement slurry no. 1

\begin{tabular}{|c|c|c|c|c|}
\hline \multicolumn{2}{|l|}{ Skład zaczynu } & \multicolumn{3}{|c|}{ Parametry zaczynu } \\
\hline Woda & $\mathrm{w} / \mathrm{c}=0,45$ & & 1,87 \\
\hline Dodatek upłynniający & $0,05 \%$ & \multicolumn{2}{|c|}{ Rozlewność [mm] } & 200 \\
\hline Dodatek antyfiltracyjny & $0,3 \%$ & \multicolumn{2}{|l|}{ Odstój wody [\%] } & 0,0 \\
\hline Dodatek odpieniający & $0,2 \%$ & \multicolumn{2}{|c|}{ Lepkość plastyczna $[\mathrm{mPa} \cdot \mathrm{s}]$} & 163,5 \\
\hline $\mathrm{KCl}$ & $3,0 \%$ & \multicolumn{2}{|c|}{ Granica plynięcia YP $[\mathrm{Pa}]$} & 3,6 \\
\hline Dodatek przyspieszający wiązanie & $1,0 \%$ & \multirow{2}{*}{ Czas gęstnienia } & $30 \mathrm{Bc}$ [h:min] & $1: 25$ \\
\hline MWCNTs & $0,1 \%$ & & $100 \mathrm{Bc}$ [h:min] & $3: 47$ \\
\hline CEM I 42,5 R & $100,0 \%$ & \multicolumn{2}{|l|}{ Porowatość [\%] } & 30,9 \\
\hline & & \multicolumn{2}{|c|}{ Filtracja $[\mathrm{ml} / 30 \mathrm{~min}]$} & 66 \\
\hline
\end{tabular}

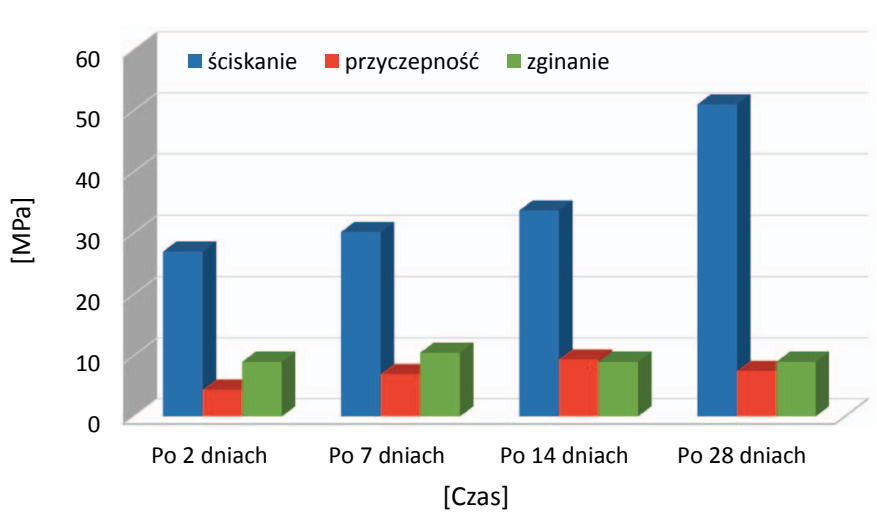

Rys. 5. Wytrzymałość mechaniczna kamienia cementowego nr 1 Fig. 5. Mechanical strength of sample 1

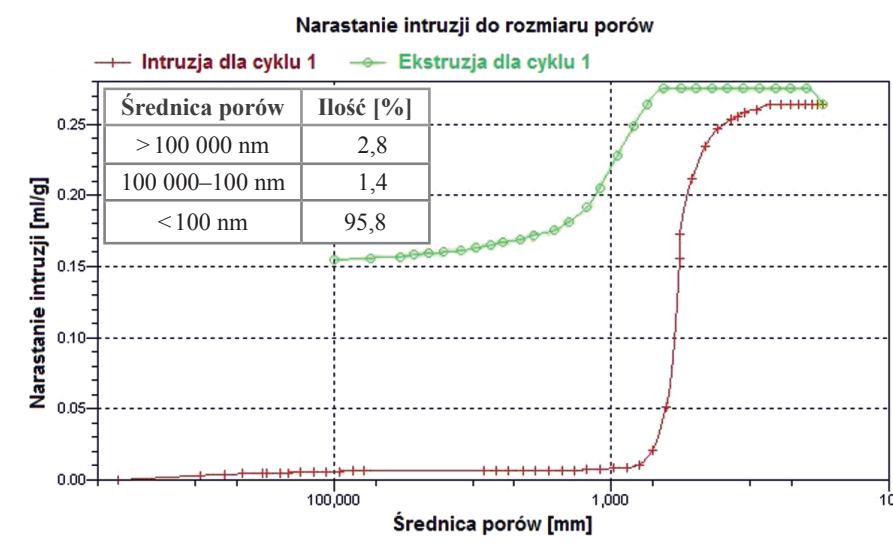

Rys. 6. Rozkład wielkości porów próbki $\mathrm{nr} 1$

Fig. 6. Pore size distribution of sample 1 
Tabela 3. Zaczyn cementowy $\mathrm{nr} 2$

Table. 3. Cement slurry no. 2

\begin{tabular}{|c|c|c|c|c|}
\hline \multicolumn{2}{|l|}{ Skład zaczynu } & \multicolumn{3}{|c|}{ Parametry zaczynu } \\
\hline Woda & $\mathrm{w} / \mathrm{c}=0,47$ & & 1,86 \\
\hline Dodatek upłynniający & $0,05 \%$ & \multicolumn{2}{|c|}{ Rozlewność [mm] } & 190 \\
\hline Dodatek antyfiltracyjny & $0,3 \%$ & \multicolumn{2}{|l|}{ Odstój wody [\%] } & 0,0 \\
\hline Dodatek odpieniający & $0,2 \%$ & \multicolumn{2}{|c|}{ Lepkość plastyczna $[\mathrm{mPa} \cdot \mathrm{s}]$} & 170,1 \\
\hline $\mathrm{KCl}$ & $3,0 \%$ & \multicolumn{2}{|c|}{ Granica płynięcia YP $[\mathrm{Pa}]$} & 3,8 \\
\hline Dodatek przyspieszający wiązanie & $1,5 \%$ & \multirow{2}{*}{ Czas gęstnienia } & $30 \mathrm{Bc}$ [h:min] & $1: 35$ \\
\hline MWCNTs & $0,1 \%$ & & $100 \mathrm{Bc}[\mathrm{h}: \min ]$ & $4: 25$ \\
\hline CEM I 42,5 R & $100,0 \%$ & \multicolumn{2}{|l|}{ Porowatość [\%] } & 32,2 \\
\hline Dodatek spęczniający & $0,3 \%$ & \multicolumn{2}{|c|}{ Filtracja $[\mathrm{ml} / 30 \mathrm{~min}]$} & 60 \\
\hline
\end{tabular}

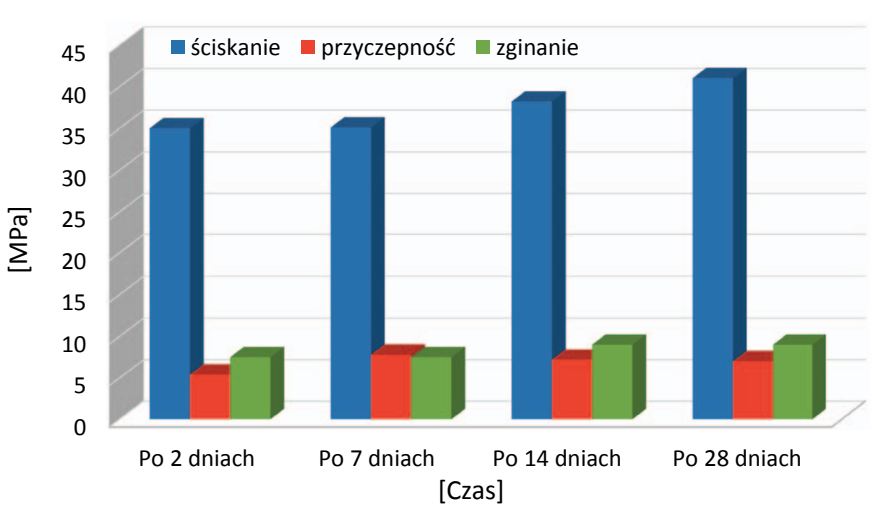

Rys. 7. Wytrzymałość mechaniczna kamienia cementowego $\mathrm{nr} 2$

Fig. 7. Mechanical strength of sample 2

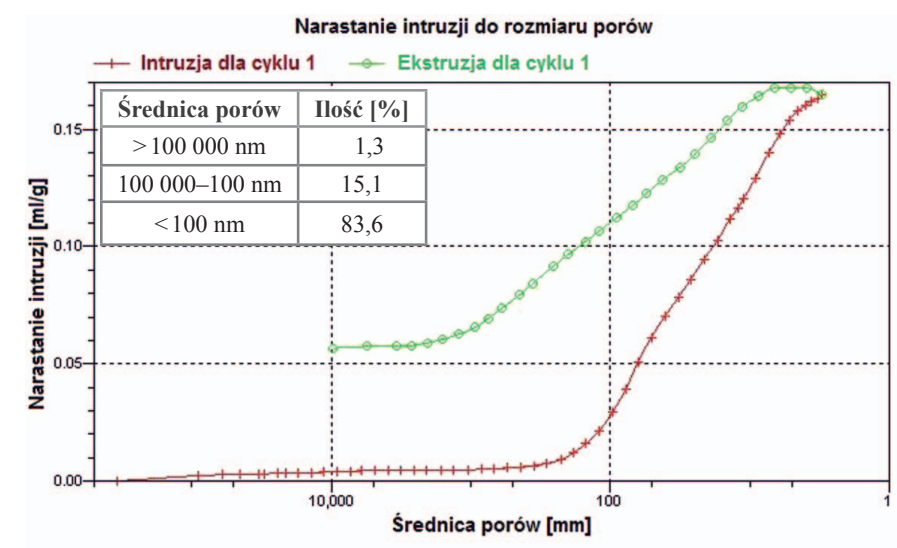

Rys. 8. Rozkład wielkości porów próbki nr 2

Fig. 8. Pore size distribution of sample 2

Tabela 4. Zaczyn cementowy nr 3

Table. 4. Cement slurry no. 3

\begin{tabular}{|c|c|c|c|c|}
\hline \multicolumn{2}{|l|}{ Sklad zaczynu } & \multicolumn{3}{|c|}{ Parametry zaczynu } \\
\hline Woda & $\mathrm{w} / \mathrm{c}=0,49$ & \multicolumn{2}{|l|}{ Gęstość $\left[\mathrm{g} / \mathrm{cm}^{3}\right]$} & 1,83 \\
\hline Dodatek upłynniający & $0,1 \%$ & \multicolumn{2}{|c|}{ Rozlewność [mm] } & 210 \\
\hline Dodatek antyfiltracyjny & $0,3 \%$ & \multicolumn{2}{|l|}{ Odstój wody [\%] } & 0,0 \\
\hline Dodatek odpieniający & $0,2 \%$ & \multicolumn{2}{|c|}{ Lepkość plastyczna $[\mathrm{mPa} \cdot \mathrm{s}]$} & 132,0 \\
\hline $\mathrm{KCl}$ & $3,0 \%$ & \multicolumn{2}{|c|}{ Granica płynięcia YP $[\mathrm{Pa}]$} & 10,6 \\
\hline Dodatek przyspieszający wiązanie & $1,0 \%$ & \multirow{2}{*}{ Czas gęstnienia } & $30 \mathrm{Bc}[\mathrm{h}: \mathrm{min}]$ & $1: 07$ \\
\hline MWCNTs & $0,2 \%$ & & $100 \mathrm{Bc}[\mathrm{h}: \mathrm{min}]$ & $4: 14$ \\
\hline CEM I 42,5 R & $100,0 \%$ & \multicolumn{2}{|l|}{ Porowatość [\%] } & 33,1 \\
\hline Dodatek spęczniający & $0,3 \%$ & \multicolumn{2}{|c|}{ Filtracja $[\mathrm{ml} / 30 \mathrm{~min}]$} & 70 \\
\hline
\end{tabular}

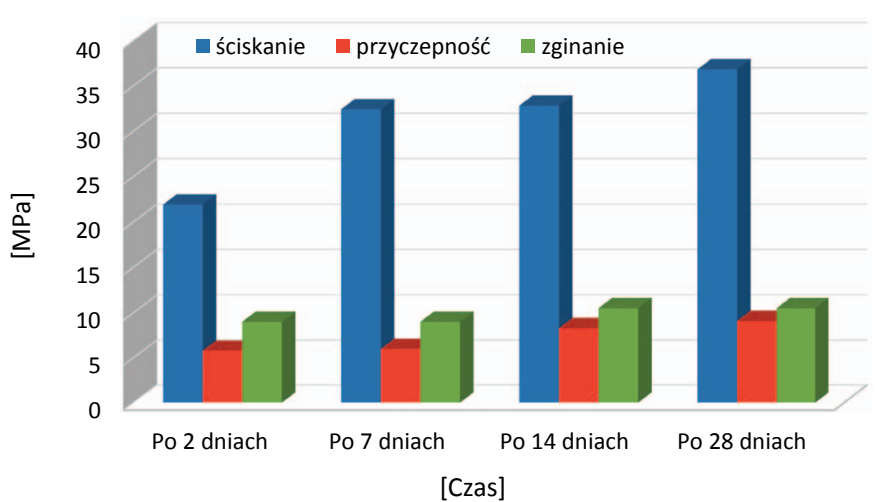

Rys. 9. Wytrzymałość mechaniczna kamienia cementowego $\mathrm{nr} 3$ Fig. 9. Mechanical strength of sample 3

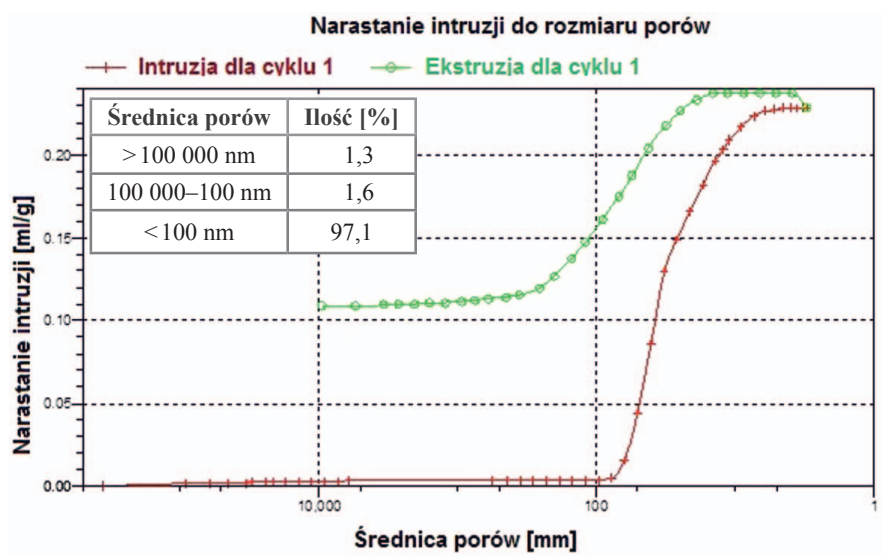

Rys. 10. Rozkład wielkości porów próbki nr 3

Fig. 10. Pore size distribution of sample 3 


\section{Wnioski}

W wyniku realizacji niniejszej pracy statutowej można wysnuć następujące wnioski:

1. Dodatek 0,1\% i 0,2\% nanorurek węglowych spowodował zmianę parametrów reologicznych zaczynu i wzrost jego gęstości. Dodatek MWCNTs spowodował spadek rozlewności zaczynów cementowych.

2. Kamienie cementowe $z$ dodatkiem nanorurek węglowych charakteryzują się niskimi porowatościami oraz małą zawartością makroporów, co świadczy o ich zwartej strukturze.

3. Można zaobserwować wzrost wytrzymałości mechanicznej kamienia cementowego po dodaniu nanocząsteczek do zaczynu. Optymalną ilością MWCNTs jest dodatek 0,1\%. W przypadku dodania $0,2 \%$ uzyskano niższe wartości wytrzymałości na ściskanie, co może być spowodowane niedostatecznym rozproszeniem nanocząsteczek w zaczynie. Największe wartości wytrzymałości na ściskanie otrzymano dla zaczynu nr 1 (51,0 MPa) oraz dla zaczynu nr 2 (41,0 MPa). W przypadku zaczynu z dodatkiem $0,2 \%$ nanorurek węglowych uzyskano wytrzymałość równą 36,8 MPa.

4. Po dodaniu nanorurek węglowych uzyskano wysokie wartości przyczepności kamienia cementowego do rur, dochodzące do 9,1 MPa (zaczyn nr 3).

5. Zaobserwowano zmniejszenie filtracji zaczynu w porównaniu z zaczynem bazowym.

W wyniku przeprowadzonych badań można zauważyć pozytywny wpływ dodatku nanorurek węglowych na wytrzymałość oraz mikrostrukturę kamieni cementowych z ich dodatkiem. Tak zmodyfikowane kamienie charakteryzują się wysokimi wartościami wytrzymałości na ściskanie oraz wysokimi przyczepnościami do rur stalowych. Kamienie cementowe posiadają zwartą mikrostrukturę o niskiej zawartości makroporów.

Przeprowadzone badania przyczyniły się do określenia wpływu nanorurek węglowych na parametry technologiczne zaczynów i kamieni cementowych stosowanych w wiertnictwie. Konieczne są dalsze badania w kierunku określenia wpływu nanorurek węglowych na właściwości zaczynu cementowego w wyższych temperaturach. Niezbędne jest również kontynuowanie badań nad określeniem optymalnych ilości tych środków oraz doborem najbardziej kompatybilnych dodatków do zaczynów cementowych działających w sposób optymalny w połączeniu z nanocząsteczkami.

Artykuł powstał na podstawie pracy statutowej pt.: Analiza możliwości zastosowania nanorurek weglowych $w$ technologii zaczynów cementowych - praca INiG - PIB na zlecenie MNiSW; nr zlecenia: 0048/KW/2019, nr archiwalny: DK-4100-0038/2019.

\section{Literatura}

Al-Saud T.S., Bin Hussain M.A.A., Batyanovskii E.I., Zhdanok S.A., Krauklis A.V., Samtsou P.P., 2011. Influence of carbon nanomaterials on the properties of cement and concrete. Journal of Engineering Physics and Thermophysics, 84(3): 546-553. DOI: 10.1007/s10891-011-0503-y.

Ando Y., 1994. The preparation of carbon nanotubes. Fullerene Science and Technology, 2(2): 173-180. DOI: 10.1080/15363839408009542.

Bachmatiuk A., 2008. Badania nad technologią otrzymywania i właściwościami nanorurek. Praca doktorska. Szczecin, Politechnika Szczecińska, Wydziat Technologii i Inżynierii Chemicznej.

Chaipanich A., Nochaiya T., Wongkeo W., Torkittikul P., 2010. Compressive strength and microstructure of carbon nanotubesfly ash cement composites. Materials Science and Engineering, 527(4): 1063-1067. DOI: 10.1016/j.msea.2009.09.039.

Collins F., Lambert J., Duan W.H., 2012. The influence of admixtures on the dispersion, workability, and strength of carbon nanotubeOPC paste mixtures. Cement and Concrete Composites, 34: 201-207. DOI: 10.1016/j.cemconcomp.2011.09.013.

Dai H., 2002. Carbon nanotubes: opportunities and challenges. Surface Science, 500: 218-241. DOI: 10.1016/S0039-6028(01)01558-8.

Dębińska E., 2014. Wpływ nanokrzemionki na parametry mechaniczne kamienia cementowego. Nafta-Gaz, 4: 229-235.

Dębińska E., 2015. Niekonwencjonalne zaczyny cementowe z dodatkiem nanokrzemionki. Nafta-Gaz, 5: 290-300.

Dębińska E., 2016. Wpływ nanotlenków glinu i cynku na parametry świeżego i stwardniałego zaczynu cementowego. Nafta-Gaz, 4: 251-261. DOI: 10.18668/NG.2016.04.04.

Dębińska E., Rzepka M., Kremieniewski M., 2016. Nanocząsteczki - nowa droga w kształtowaniu parametrów świeżych i stwardniałych zaczynów cementowych. Nafta-Gaz, 12: 1084-1091. DOI: 10.18668/NG.2016.12.11.

Dobrzańska-Danikiewicz A.D., Łukowiec D., Cichocki D., Wolany W., 2015. Nanokompozyty złożone z nanorurek węglowych pokrytych nanokryształami metali szlachetnych. Open Access Library, Annal V, 2: 1-131.

Dresselhaus M.S., Dresselhaus G., Eklund P.C., 1996. Science of Fullerenes and Carbon Nanotubes: Their Properties and Applications. Academic Press, San Diego, California.

Eberhardsteiner J., Zhdanok S., Khroustalev B., Batsianouski E., Leonovich S., Samtsou P., 2011. Characterization of the influence of carbon nanomaterials on the mechanical behavior of cement stone. Journal of Engineering Physics and Thermophysics, 84(4): 697-704. DOI: 10.1007/s10891-011-0531-7.

Hielscher T., 2006. Ultrasonic production of nano-size dispersions and emulsions. ENS'05, December, Paris, France: 138-143.

Huang X., Qi Y., Boey F., Zhang H., 2012. Graphene based composites. Chemical Society Reviews, 41(2): 666-686. DOI: 10.1039/ c1cs15078b.

Iijima S., Ichihashi T., 1993. Single-Shell Carbon Nanotubes of 1-nm Diameter. Nature, 363: 603-605. DOI: 10.1038/363603a0.

Kosta-Gdoutos M.S., Metaxa Z.S., Shah S.P., 2010. Multi-scale mechanical and fracture characteristics and early-age strain capacity of high performance carbon nanotube/cement nanocomposites. Cement and Concrete Composites, 32(2): 110-115. DOI: 10.1016/j.cemconcomp.2009.10.007.

Kuilla T., Bhadra S., Yao D., Kim N.H., Bose S., Lee J.H., 2010. Recent advances in graphene based polymer composites. Progress in Polymer Science, 35(11): 1350-1375. DOI: 10.1016/j.progpolymsci.2010.07.005.

Li G.Y., Wang P.M., Zhao X., 2005. Mechanical behavior and 
microstructure of cement composites incorporating surface-treated multi-walled carbon nanotubes. Carbon, 43(6): 1239-1245. DOI: 10.1016/j.carbon.2004.12.017.

Li X., Cao A., Jung Y.J., Vajtai R., Ajayan P.M., 2005. Bottom-up growth of carbon nanotube multilayers: unprecedent growth. Nano Letters, 5(10): 1997-2000. DOI: 10.1021/n1051486q.

Maser W.K., Benito A.M., Martinez M.T., 2002. Production of carbon nanotubes: the light approach. Carbon, 40(10): 1685-1695. DOI: 10.1016/S0008-6223(02)00009-X.

de Morais J.F., Haddad A.N., 2014. Analysis by ultrasound of the behavior of carbon nanotubes on cementitious composites. Journal of Nanotechnology and Advance Materials, 2(2): 89-98. DOI: 10.12785/jnam/020206.

Musso S., Porro S., Giorcelli M., Chiodoni A., Ricciardi C., Tagliaferro A., 2007. Macroscopic growth of carbon nanotube mats and their mechanical properties. Carbon, 45(5): 1133-1136. DOI: 10.1016/j.carbon.2006.12.019.

Musso S., Tulliani J-M., Ferro G., Tagliaferro A., 2009. Influence of carbon nanotubes structure on the mechanical behavior of cement composites. Composites Science and Technology, 69(11-12): 1985-1990. DOI: 10.1016/j.compscitech.2009.05.002.

Nasibulin A.G., Koltsiva T., Nasibulin L.I., Anoshkin I.V., Semencha A., Tolochko O.V., Kauppinen E.I., 2013. A novel approach to composite preparation by direct synthesis of carbon nanomaterial on matrix or filler particles. Acta Materialia, 61(6): 1862-1871. DOI: 10.1016/j.actamat.2012.12.007.

Nochaiya T., Chaipanich A., 2011. Behavior of multi-walled carbon nanotubes on the porosity and microstructure of cement-based materials. Applied Surface Science, 257(6): 1941-1945. DOI: 10.1016/j.apsusc.2010.09.030.

Oncel C., Yurum Y., 2006. Carbon nanotube synthesis via the catalytic CVD method: a review on the effect of reaction parameters. Fullerene, Nanotubes, Carbon Nanostructures, 14(1): 17-37. DOI: 10.1080/15363830500538441.

Pandey P., Dahiya M., 2016. Carbon Nanotubes: Types, Methods of Preparation and Applications. International Journal of Pharmaceutical Science and Research, 1(4): 15-21.

Patil R., Deshpande A., 2012. Use of Nanomaterials in Cementing Applications. Society of Petroleum Engineers. DOI: 10.2118/155607-MS.

Popov V.N., 2004. Carbon nanotubes: properties and application. Materials Science and Engineering: R: Reports, 43(3): 61-102. DOI: 10.1016/j.mser.2003.10.001.

Puretzky A.A., Geohegan D.B., Fan X., Pennycook S.J., 2000. In situ imaging and spectroscopy of single-wall carbon nanotube synthesis by laser vaporization. Applied Physics Letters, 76(2): 182-184. DOI: 10.1063/1.125696.

Rahman M.K., Khan W.A., Mahmoud M.A., Sarmah P., 2016. MWCNT for Enhancing Mechanical and Thixotropic Properties of Cement for HPHT Applications. Offshore Technology Conference. DOI: $10.4043 / 26465-M S$.

Rahman M.K., Murtaza M., 2015. Effect of Nanoclay on Mechanical and Rheological Properties of Oil Well Cement Slurry under HPHT Environment. International Petroleum Technology Conference. DOI: 10.2523/IPTC-18989-MS.

Roij R., Egyed C., Lips J., 2012. Nano-engineered Oil Well Cement Improves Flexibility and Increases Compressive Strength: A Laboratory Study. Society of Petroleum Engineers. DOI: 10.2118/156501-MS.
Saeed K., Khan I., 2013. Carbon nanotubes-properties and applications: A review. Carbon Letters, 14(3): 131-144. DOI: 10.5714/ CL.2013.14.3.131.

Sàez de Ibarra Y., Gaitero J.J., Erkizia E., Campillo I., 2006. Atomic force microscopy and nanoindentation of cement pastes with nanotube dispersions. Physica Status Solid A, 203(6): 1076-1081. DOI: $10.1002 /$ pssa.200566166.

Sobolkina A., Mechtcherine V., Khavrus V., Maier D., Memde M., Ritschel M., Leonhardt A., 2012. Dispersion of carbon nanotubes and its influence on the mechanical properties of cement matrix. Cement and Concrete Composites, 34(10): 1104-1113. DOI: 10.1016/j.cemconcomp.2012.07.008.

Szadkowski B., Pingot M., 2016. Nanorurki węglowe - materiał przyszłości. Eliksir, 1: 16-19.

Taniguchi N., 1974. On the basic concept of nanotechnology. Proceedings of the International Conference on Production Engineering, Tokyo, Japan, Part II.

Wang B., Han Y., Liu S., 2013. Effect of highly dispersed carbon nanotubes on the flexural toughness of cement-based composites. Construction and Building Materials, 46: 8-12. DOI: 10.1016/j. conbuildmat.2013.04.014.

\section{Akty prawne i normatywne}

PN-EN ISO 10426-1:2009 Przemyst naftowy i gazowniczy - Cementy i materiały do cementowania otworów-Część 1: Specyfikacja.

PN-EN ISO 10426-2:2003 Przemyst naftowy i gazowniczy-Cementy i materiały do cementowania otworów wiertniczych-Część 2: Badania cementów wiertniczych.

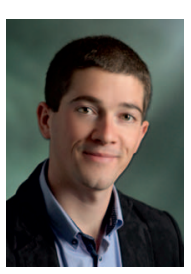

Mgr inż. Miłosz KĘDZIERSKI

Specjalista inżynieryjno-techniczny w Zakładzie

Technologii Wiercenia

Instytut Nafty i Gazu - Państwowy Instytut Badawczy ul. Lubicz $25 \mathrm{~A}$

31-503 Kraków

E-mail: milosz.kedzierski@inig.pl

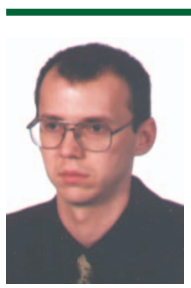

Dr inż. Marcin RZEPKA

Kierownik Laboratorium Zaczynów Uszczelniających w Zakładzie Technologii Wiercenia Instytut Nafty i Gazu - Państwowy Instytut Badawczy ul. Lubicz $25 \mathrm{~A}$

31-503 Kraków

E-mail: marcin.rzepka@inig.pl

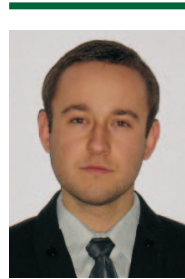

Dr inż. Marcin KREMIENIEWSKI

Adiunkt w Zakładzie Technologii Wiercenia Instytut Nafty i Gazu - Państwowy Instytut Badawczy ul. Lubicz 25 A

31-503 Kraków

E-mail:marcin.kremieniewski@inig.pl 